\title{
Lithogeochemistry and 3D geological modeling of the apatite-bearing Mesquita Sampaio beforsite, Jacupiranga alkaline complex, Brazil
}

\author{
Saulo Batista de Oliveira ${ }^{1 *}$ (D), Lilia Mascarenhas Sant'Agostino² (1)
}

\begin{abstract}
The Mesquita Sampaio beforsite is a mineral exploration area with apatite mineralization occurring near the northern portion of the Morro da Mina apatite deposit (Cajati Mine), in the Jacupiranga Alkaline Complex. This study presents the mineralogical, geochemical and 3D geological modeling data of this target. Four lithotypes are presented for Mesquita Sampaio: the fine-grained beforsite (FGB), the coarse-grained beforsite (CGB), the xenolith zone (XEN), and the jacupirangite (JAC). The 3D geological model shows the Mesquita Sampaio beforsite as a vertical body with an NNW direction and approximately 350 meters in length, 150 meters in width, and 400 meters of depth, with open extensions. The main mineral assemblage of the beforsite is dolomite, apatite, phlogopite, serpentine, calcite, and magnetite, in order of abundance. The distribution of major elements for both types of beforsites (FGB and CGB) indicates the same composition with only a small variation in the mineral proportions. Although no direct contact relation between Mesquita Sampaio and Morro da Mina is known, both may be the same carbonatite body with a gradual compositional variation, or the Mesquita Sampaio beforsite could be a distinct late or even earlier carbonatite pipe.
\end{abstract}

KEYWORDS: carbonatite; Jacupiranga Alkaline Complex; Cajati Mine; beforsite; Mesquita Sampaio; apatite; lithogeochemistry; 3D geological modeling.

\section{INTRODUCTION}

The Jacupiranga Alkaline Complex is a classical Brazilian occurrence of mineral deposit in alkaline rocks province with associated carbonatite, congregating facilities of mine and a chemical-industrial complex. These facilities refer to the company Mosaic Fertilizantes, which currently develops mining activity in the main carbonatite body for the apatite extraction as an ore for phosphate production. The Mesquita Sampaio area is located approximately at latitude $24{ }^{\circ} 40^{\prime} 33.0^{\prime \prime} \mathrm{S}$ and longitude $48^{\circ} 08^{\prime} 04.0^{\prime \prime} \mathrm{W}$, in the vicinity of the northern portion of the Morro da Mina, the name given to the Cajati mine, and presents mineral resources that are in the mineral exploration stage. The Morro da Mina phosphate deposit is located in the Cajati town, Vale do Ribeira region, in the southeast of São Paulo State, close to the border with Paraná State and about $240 \mathrm{~km}$ from the city of São Paulo.

This work is the first geological description of the Mesquita Sampaio beforsite, bringing the initial mineralogical, geochemical, and 3D modeling aspects. This paper introduces and

${ }^{1}$ Instituto de Geociências, Universidade de São Paulo - São Paulo (SP), Brazil. E-mail: sauloboliveira@hotmail.com

${ }^{2}$ Ministério de Minas e Energia, Esplanada dos Ministérios - Brasília (DF), Brazil. E-mail: lilia.santagostino@mme.gov.br

${ }^{*}$ Corresponding author. discusses the first data available from the Mesquita Sampaio, which were obtained from drill hole samples, and compares the mineralogical, textural, and geochemical aspects of the beforsite with the available data in the literature from the contiguous Morro da Mina apatite deposit.

\section{GEOLOGIC SETTING}

\section{Jacupiranga Alkaline Complex}

Morro da Mina and Mesquita Sampaio are inserted in the Jacupiranga Alkaline Complex, a classic Brazilian occurrence of alkaline and ultrabasic rocks with associated carbonate manifestations that contemplate a phosphate deposit of magmatic affiliation. The main carbonate body presents a structure interpreted as a diatreme, discovered by Bauer (1877) and preliminarily investigated at the end of the nineteenth century by Derby (1891) and Hussak (1892). More detailed studies (Melcher $1965,1966)$ came with the removal of the weathering mantle with the open-pit mining activities on the Morro da Mina carbonate body. The mining of high-grade weathered ore ( $>25 \%$ $\mathrm{P}_{2} \mathrm{O}_{5}$ ) lasted until the mid-1960s, when the economic base of the deposit began to undergo changes, initiating the mining of the non-weathering carbonate body mineralized to apatite, with average contents around $5 \%$ of $\mathrm{P}_{2} \mathrm{O}_{5}$. Thus, more detailed studies on the deposit structural geology and mineralogy became possible (Gaspar and Wyllie 1983a, 1983b, Menezes and Martins 1984, Gaspar 1989). K-Ar radiometric analysis on 
carbonatites of the complex yield an age of $130 \pm 5 \mathrm{Ma}$ (Amaral 1978), subsequently confirmed by $\mathrm{Rb}-\mathrm{Sr}$ age of $131 \pm 3 \mathrm{Ma}$ (Roden et al. 1985), and by ${ }^{40} \mathrm{Ar} /{ }^{39} \mathrm{Ar}$ ages for different lithotypes of Jacupiranga Alkaline Complex ranging from $133.7 \pm$ 0.5 to $131.4 \pm 0.5 \mathrm{Ma}$ (Chmyz et al. 2017). In relation to the tectonics, several authors such as Almeida (1983), Ruberti et al. (2005), and Gomes et al. (2011), among others, point out an association between the rocks of the Jacupiranga Alkaline Complex and the Guapiara Lineament, where the Mesozoic alkaline magmatic activity would have been conditioned by the
Ponta Grossa Arch (Fig. 1). Germann et al. (1987) presents a geological map in which the complex shows an oval shape of approximately $70 \mathrm{~km}^{2}$, with NNW direction, and is completely embedded into the Precambrian rocks of the Açungui Group (550 Ma) (Fig. 2). The carbonatite host rocks are mafic alkaline rocks, represented by jacupirangite and dunite, bordered by a zone of assimilation in the northern region. It is worth mentioning that the jacupirangite, originally defined by Derby (1891), designates a pyroxenite constituted essentially by titanian augite, magnetite, and nepheline, with biotite and

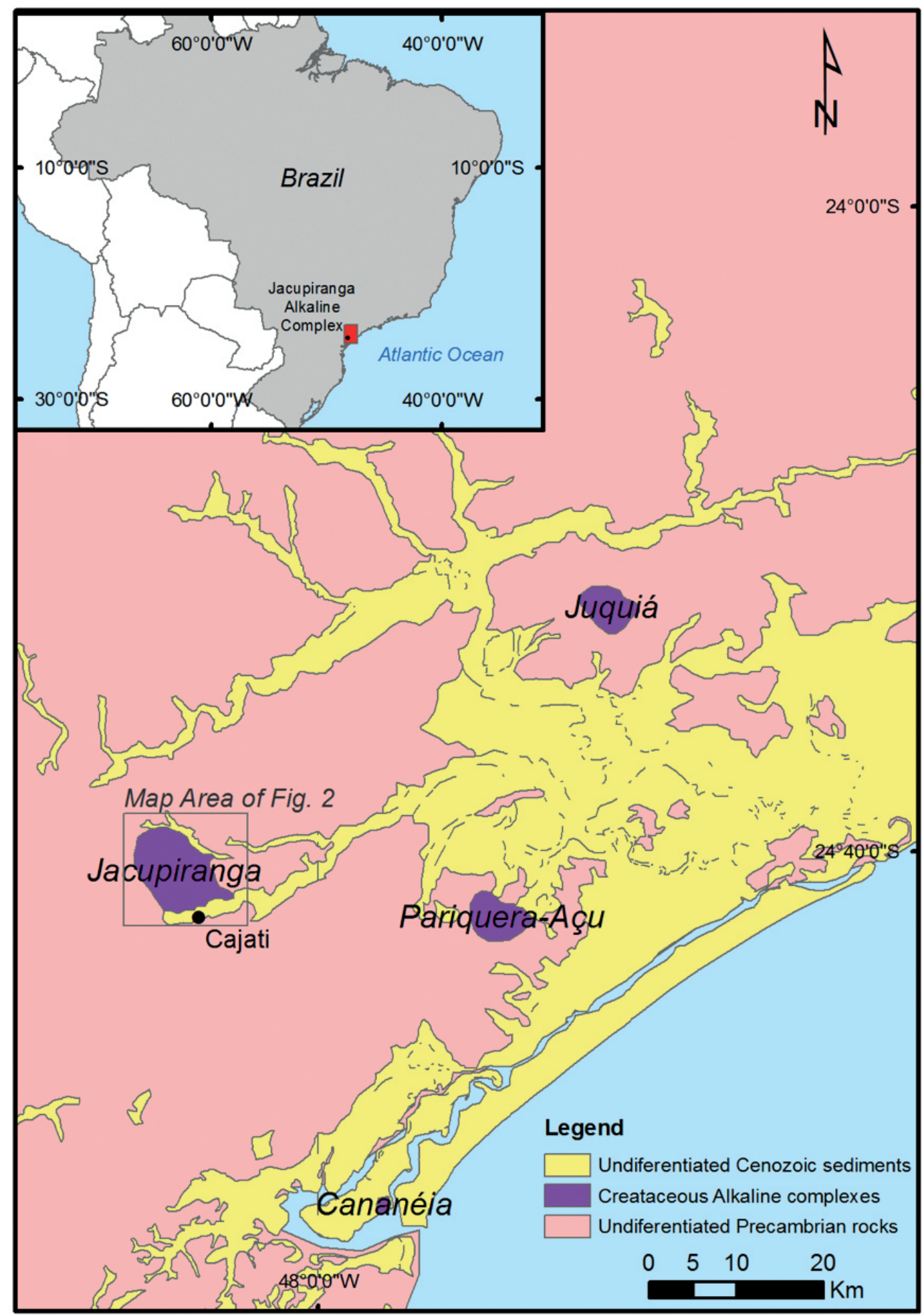

Figure 1. Schematic regional geological map of Jacupiranga, Juquiá, Pariquera-Açu, and Cananéia alkaline complexes at the Guapiara Lineament (after Ruberti et al. 2005). 
olivine as accessories, being the presence of such pyroxene in the rock is a fundamental characteristic for its definition. In this work, all pyroxenite hosting the carbonatite in Morro da Mina and Mesquita Sampaio areas are treated indistinctly as jacupirangite, due to the widespread use of the term in the mine. The alkaline intrusion also presents other types of pyroxenites, serpentinized peridotite, ijolite, nepheline syenite, fenite and, more in the center, carbonatite, the object of this work, in addition to other types of alkaline rocks of lesser expression, that occur mainly in the form of dikes, like melteigite and phonolite.

\section{Morro da Mina carbonatite (Cajati apatite mine)}

Specifically considering carbonatite, the portion of the Jacupiranga Alkaline Complex where the apatite mine is installed, perhaps the first work of major importance are Gaspar and Wyllie (1983a, 1983b), which identified five phases of carbonatitic intrusions, and not only two (Melcher 1965, 1966), and their chronological sequence, having the jacupirangite as host rock.

Thus, this magmatic structure is interpreted as a volcanic chimney breccia, with narrow and inverted conical shape, resulting from the subvolcanic explosion of carbonate volcanic magma that, when reaching shallow depths of the crust, caused the sudden gas expansion as fluidized magma, involving fragments of the ducts, in this case, of jacupirangite xenoliths, and of the carbonatite itself. A striking feature of this contact is the presence of reaction zones or fenitization, corresponding to a layer of carbonate minerals and newly formed silicates, generated from the interaction of carbonatite and jacupirangite, whose thickness varies from millimeters to centimeters, and can reach around 30 centimeters. Morbidelli et al. (1986) elaborate a detailed study on reaction zone describing a sequence from the jacupirangite to the carbonatite, which begins with the amphibole-rich band (A), then the phlogopite-rich band $(\mathrm{P})$, and finally olivine-rich band $(\mathrm{O})$. The A band occurs in the jacupirangite contact, where the amphibole is a pyroxene pseudomorph. It has a variable thickness of 1 to 5 centimeters, dark green color, interspersed with millimeter bands of

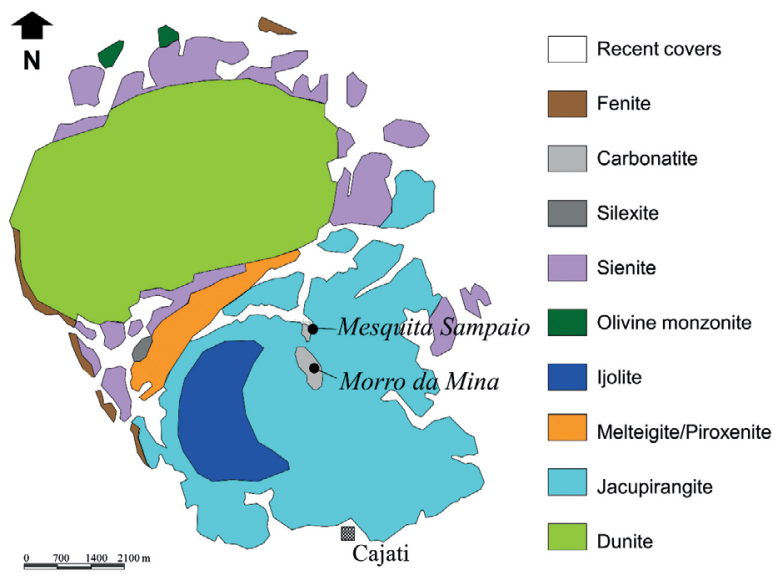

Figure 2. Geological map of the Jacupiranga Alkaline Complex (compiled and modified from Melcher 1966, Germann et al. 1987, Faleiros and Pavan 2013) with the Mesquita Sampaio and the Morro da Mina carbonatites locations. carbonates, in a well-defined banding, with the occurrence of phlogopite and magnetite. The most developed $\mathrm{P}$ band consists essentially of phlogopite, in addition to ilmenite and magnetite, the banded structure does not occur regularly in some portions as spots, and it presents a variable thickness from a few centimeters to 1 meter and red wine color. The external $\mathrm{O}$ band contains, in addition to abundant olivine, phlogopite, magnetite, and ilmenite, centimetric to decimetric band thickness with a very dark color, almost black, and the banded structure is less regular than in previous phases, commonly olivine crystals are strongly affected by serpentinization. The carbonate phase can occur as bands, spots or veins, and are essentially of calcitic composition. In general, they present associated apatite, well developed in the $\mathrm{P}$ band, in addition to phlogopite and amphibole.

Menezes and Martins (1984) divided the mineral assemblage of the Morro da Mina deposit into two groups: those found in carbonatite and those found in jacupirangite. The complete list consists of 53 species. In carbonatite, these authors observed: ancylite, aragonite (secondary), baddeleyite, barite, brucite, calcite (primary and secondary), chalcopyrite, titanclinohumite, dolomite, strontianite, phlogopite, fluorapatite, forsterite, galena, geikielite, magnetite, manasseite, pyrite, pyrrhotite, quartz (secondary), quintinite, serpentine group minerals, uranpyrochlore, and valerite. In turn, the minerals found in jacupirangite, according to these authors, are: aegirine, titan-andradite, titan-augite, barite, biotite, calcite, calzirtite, diopside, dolomite, edingtonite, phlogopite, fluorapatite, forsterite, hornblende, magnesium-ilmenite, magnetite, natrolite, nepheline, perovskite, pyrite, pyrrhotite, richterite, schorlomite, tazheranite, titanite, tochilinite, tremolite, vesuvianite, vigezzite, wollastonite, zircon, zirconolite, and zirkelite.

With the geological and chemical control of the mining activities and the detailed mapping of the mining fronts, it was possible to elaborate a map with detail of structural features (magmatic foliation and mineral lineation) of five intrusive phases, and the development of a structural model of the main carbonatite body in geometric and evolutionary terms (Gaspar and Wyllie 1983b). The intrusions of the southern portion were denominated: $\mathrm{C}_{1}, \mathrm{C}_{2}, \mathrm{C}_{3}$ and those of the northern portion: $\mathrm{C}_{4}$ and $\mathrm{C}_{5}$. The intrusions of the southern portion were subdivided into two parts: north and south. The sequence of carbonate intrusions, from the oldest to the newest, is $\mathrm{C}_{1}, \mathrm{C}_{2}, \mathrm{C}_{3}, \mathrm{C}_{4}$, and $\mathrm{C}_{5}$.

According to Gaspar and Wyllie (1983b), $C_{1}$ is a coarsely-banded sovite composed of calcite, apatite, magnetite, olivine, phlogopite, dolomite, and sulfides, with all mineralogy being described in abundance order. The banding is usually subvertical dipping north. The apatite lineation is always subhorizontal. Two southern regions can be individualized because they are poor in non-carbonaceous minerals. However, outside these regions, the sovite is rich in olivine, magnetite, and apatite, and inside these regions, it contains apatite and phlogopite. The $\mathrm{C}_{2}$ intrusion was described as a finely banded sovite consisting of calcite, apatite, magnetite, olivine, phlogopite, dolomite, and sulfides. It has a vertical dip, parallel to the contact with $\mathrm{C}_{1}$, and the apatite lineation is subhorizontal. Sovite and beforsite with diffuse banding were observed in the contact between $\mathrm{C}_{2}$ 
and $\mathrm{C}_{3}$. The $\mathrm{C}_{3}$ intrusion is a medium-to-thick grained sovite, with a less evident banding, composed of calcite, apatite, magnetite, phlogopite, dolomite, olivine, and sulfide. The $\mathrm{C}_{3}$ body has a different characteristic from the other places: in its center, the dip varies from 20 to $40^{\circ}$ to the north, it becomes steeper in the edges, and vertical in other places. The apatite lineation is usually parallel to the main magmatic foliation dip. In the northern part, the $\mathrm{C}_{4}$ body was described as a sovite composed of calcite, apatite, magnetite, olivine, phlogopite, dolomite, and sulfides in the form of a cylindrical intrusion with vertical banding parallel to the edges, and with subhorizontal mineral lineation. Finally, the $\mathrm{C}_{5}$ intrusion, which was described as a medium- to coarse-grained rauhaugite, is composed of dolomite, apatite, phlogopite, magnetite, sulfides, and calcite. $\mathrm{C}_{5}$ cuts $\mathrm{C}_{4}$ intrusion and has banded with a dip near $80^{\circ}$ to the north. The apatite lineation is parallel to the dip.

Due to difficulties in mineral processing associated with the necessity to reevaluate the deposit, Saito et al. (2004) present a refinement of the Morro da Mina carbonatite body, identifying a total of twelve geological units that take into account not only geological characteristics but also relevant characteristics of the rock as ore in the beneficiation plant (Fig. 3). In addition to the definitions by Gaspar and Wyllie (1983b), the authors distinguished seven exclusively carbonate units $(1,2,3,6,7,8$, and 9$)$ with distinct petrographic characteristics, mappable contacts, and a distinct internal organization with concentric flow foliation and presence of xenoliths in the contact regions. Correlating the twelve units from Saito et al. (2004) with the five intrusions of Gaspar and Wyllie (1983b), carbonatite units 1 to 3 correspond to the $C_{1}$ intrusion, units 6 to 8 correspond to the $\mathrm{C}_{2}$ intrusion, unit 6 also corresponds to $\mathrm{C}_{3}$, unit 9 corresponds to $\mathrm{C}_{4}$, and apparently, dolomite carbonatite (unit 11) corresponds to $\mathrm{C}_{5}$. In addition to them, Saito et al. (2004) defined some isolated metric lenses of phoscorite in the north and south mine regions (units 4 and 10), and a coarse-grained dolomite carbonatite (unit 11) occurring as late carbonate alteration products
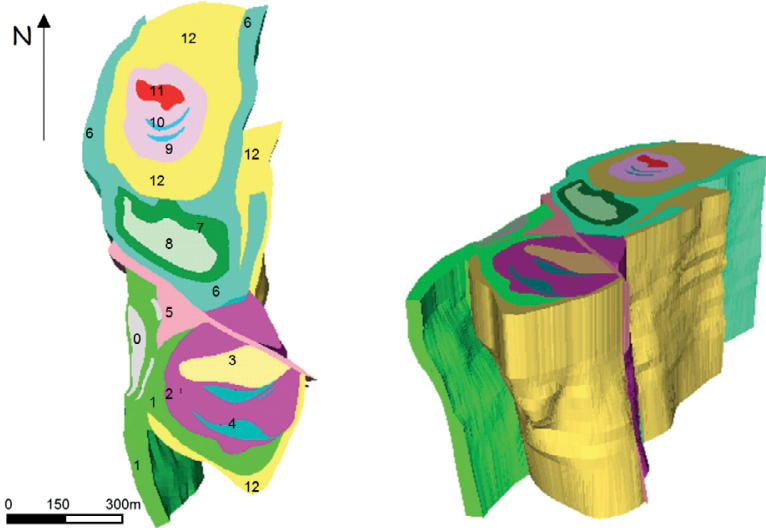

Figure 3. 3D geological model of Morro da Mina deposit (Saito et al. 2004). Geological units: 1) South Peripheral Carbonatite; 2) South Calcitic Carbonatite; 3) Oxidized Carbonatite; 4) South Phoscorite Zone; 5) Fault Zone; 6) Intermediate Carbonatite; 7) Foliated Carbonatite; 8) White Carbonatite; 9) North Carbonatite; 10) North Phoscorite Zone; 11) Dolomite Carbonatite; 12) Xenolith Zones; 0) Jacupirangite. (dolomitization). In addition to the north xenolith zone mapped by Gaspar (1989), two other regions were identified in the east and south zones, where the centimetric to metric xenoliths are jacupirangite with metasomatized borders, sometimes supported by a carbonaceous matrix. The fault zone (unit 5) corresponds to the main fault of a brittle shear regime that produced the main fault system and subsidiary faults, with $\mathrm{N} 75 \mathrm{~W} /$ subvertical direction with a sinistral shear component. The fault zone produced a series of products such as breccias, cataclasites, and gouges, in addition to allowing the pervasive to fissural alteration and oxidation of the carbonatite in different intensities.

\section{MATERIALS AND METHODS}

The Mesquita Sampaio is a mineral exploration area right in the northern portion of the Morro da Mina carbonatite body, the Cajati apatite mine (Fig. 4). This study is based on core samples of the first eleven exploratory drillholes, which are all inclined at $45^{\circ}$, and distributed around the Mesquita Sampaio area in a regular spacing of 100 meters. Three drillholes were performed in the 2000 drilling campaign, identified as SP21, SP22, and SP24, and eight drillholes, SP42, SP43, SP44, SP45, SP46, SP47, SP48, and SP50, in the 2003 campaign, totaling 4,428 meters in the study area. The database provided by the company contains the drillhole log data and chemical analysis. All whole-rock core samples (with an average length of three meters) were analyzed by X-ray fluorescence (XRF), for $\mathrm{CaO}$, $\mathrm{MgO}, \mathrm{SiO}_{2}, \mathrm{Al}_{2} \mathrm{O}_{3}, \mathrm{Fe}_{2} \mathrm{O}_{3}, \mathrm{P}_{2} \mathrm{O}_{5}, \mathrm{TiO}_{2}, \mathrm{SrO}, \mathrm{MnO}$, and loss on ignition (LOI), with pressed powder samples, using an Axios Advanced spectrometer with sequential wavelength detector and the SuperQ software, both from PANalytical, in the internal mine laboratory, following routine procedures of the company (Sant'Agostino et al. 2001). Not all database samples were analyzed for all elements. Four beforsite samples with chemical analysis were selected for petrographic studies on thin sections using a Leica DM750P optical microscope.

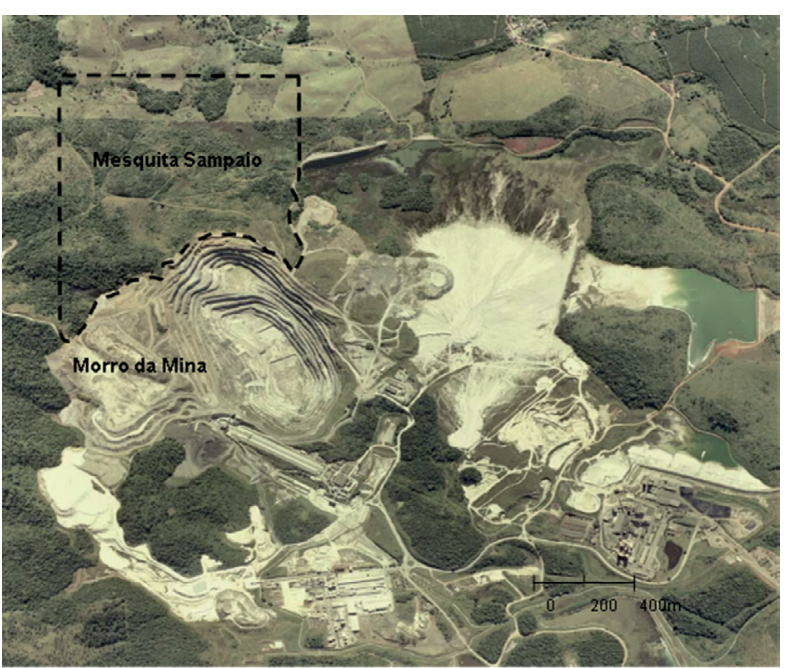

Figure 4. Aerial photo with the location of the Morro da Mina open pit and the Mesquita Sampaio exploration target (approximate scale) 
$\mathrm{X}$-ray diffraction (XRD) analyses were performed on eighteen Mesquita Sampaio carbonatite samples, macroscopically selected as the most representative of the two beforsites, on Philips-MPD 1880 equipment, with PW1710 controller and X'Pert Data Collector software in the Laboratório de Caracterização Tecnológica at Universidade de São Paulo (LCT-USP). The operating conditions were standardized in a step scan of $0,02^{\circ}$ with a time/step of $40 \mathrm{~s}$, range from $2 \theta 2.5$ to 70.0 , analysis time per sample of $20 \mathrm{~min}, \mathrm{Cu}(\mathrm{K \alpha l}=1.5405981$ A), $45 \mathrm{kV}$ voltage, $40 \mathrm{~mA}$ current, spinner on, and graphite monochromator. The identification of the present phases was carried out using X'Pert High Score Plus software and International Center for Diffraction Data (ICDD) PDF-2 database.

\section{MESQUITA SAMPAIO LITHOTYPES}

The classification in lithotypes presented here originates from the geological model elaborated by the research team of the company, which followed the same standards applied to the geological model of Morro da Mina apatite deposit (Sant'Agostino et al. 2001, Bonas 2007). The classification presents the main characteristics of the rocks that influence the current ore beneficiation process, such as rock grain size, amount of macroscopically recognizable mineral species, and grain size of these minerals, highlighting apatite and carbonates as ore minerals, and magnetite and phlogopite as gangue ones (Tab. 1). Four lithotypes were defined, three of them for ore units: the fine-grained beforsite (FGB), the coarse-grained beforsite (CGB), and the xenolith zone (XEN), and one for barren material: the jacupirangite (JAC), described in detail below. The most notable attribute that differentiates the two carbonatite lithotypes is grain size, defining so, the FGB and the CGB. In addition to the grain size, another distinctive feature between these two units is the color, the FGB exhibits a more grayish color compared to the CGB, which is whiter (Fig. 5).

Table 1. Mesquita Sampaio lithotypes definition parameters.

\begin{tabular}{|c|c|c|c|c|}
\hline \multirow{2}{*}{ Lithotype } & \multirow[t]{2}{*}{ Grain size } & \multicolumn{3}{|c|}{ Mineralogy } \\
\hline & & Mineral & Grain size & Amount \\
\hline \multirow{5}{*}{$\begin{array}{l}\text { Fine-grained } \\
\text { beforsite (FGB) }\end{array}$} & \multirow{5}{*}{$2 \mathrm{~mm}$} & Carbonates & $2 \mathrm{~mm}$ & $70 \sim 90 \%$ \\
\hline & & Apatite & $1 \mathrm{~mm}$ & $5 \sim 10 \%$ \\
\hline & & Magnetite & $3 \mathrm{~mm}$ & $5 \sim 15 \%$ \\
\hline & & Phlogopite & $2 \mathrm{~mm}$ & $5 \%$ \\
\hline & & \multicolumn{3}{|c|}{$\begin{array}{c}\text { Accessories: olivine locally and } \\
\text { disseminated sulfide associated } \\
\text { with magnetite. }\end{array}$} \\
\hline \multirow{6}{*}{$\begin{array}{l}\text { Coarse-grained } \\
\text { beforsite (CGB) }\end{array}$} & \multirow{6}{*}{$4 \sim 7 \mathrm{~mm}$} & Mineral & Grain size & Amount \\
\hline & & Carbonates & $3 \sim 5 \mathrm{~mm}$ & $65 \sim 85 \%$ \\
\hline & & Apatite & $1 \mathrm{~mm}$ & $10 \sim 15 \%$ \\
\hline & & Magnetite & $5 \mathrm{~mm}$ & $5 \%$ \\
\hline & & Phlogopite & $3 \mathrm{~mm}$ & $5 \%$ \\
\hline & & Accesso & ries: sulfide & locally \\
\hline \multirow{6}{*}{$\begin{array}{l}\text { Xenolith zone } \\
\text { (XEM) }\end{array}$} & \multirow{6}{*}{$2 \sim 5 \mathrm{~mm}$} & Mineral & Grain size & Amount \\
\hline & & Silicates & $1 \mathrm{~mm}$ & $60 \sim 80 \%$ \\
\hline & & Fe oxides & $2 \mathrm{~mm}$ & $10 \sim 20 \%$ \\
\hline & & Carbonates & $1 \sim 3 \mathrm{~mm}$ & $20 \sim 30 \%$ \\
\hline & & Apatite & $1 \mathrm{~mm}$ & $5 \%$ \\
\hline & & Accesso & ries: sulfide & locally \\
\hline
\end{tabular}

\section{Coarse-grained beforsite (CGB)}

CGB is a coarse-grained white dolomite carbonatite, with finegrained apatite, fine-grained magnetite sometimes ragged in small amount, and fine-grain phlogopite with sulfides locally (Fig. 5A). There are also small portions with very fine-grained concentrated greenish apatite with a common association oflargemagnetite crystals. Thelineation of these mineralsis notas marked as observed in theFGB.

\section{Fine-grained beforsite (FGB)}

The FGB comprises a fine-grained white to gray dolomite carbonatite with fine-grained apatite, fine-grained phlogopite locally with sulfides associated with magnetite, and glimmerite stains (Fig. 5B). The apatite is mostly euhedral, with greenish color, usually concentrated in small portions locally, and sometimes presents association with magnetite in a well-marked subvertical lineation.

\section{Xenolith Zone (XEN)}

This unit is characterized by the predominance of decimetric to metrics jacupirangite intercalations (Fig. 5C), with reaction edges (fenitization), sometimes stained or flocked, marked by the alternation of millimetric to centimetric levels of grayish calcitic carbonatite with glimmerite, serpentine, and olivine. Both these silica phases and the grayish calcitic carbonatite levels may occur very thick locally.

\section{Jacupirangite (JAC)}

It is very similar to the jacupirangite described in Morro da Mina, a dark green to black color rock, composed of mafic minerals (pyroxenes and magnetite). In regions of contact with carbonatites, there are small portions composed of phlogopite, magnetite, and olivine, with zones of reaction reaching up one meter in thickness.

\section{RESULTS}

\section{D geological modeling}

The three-dimensional (3D) digital geological modeling has the main objective to compartmentalize rock units in the space,
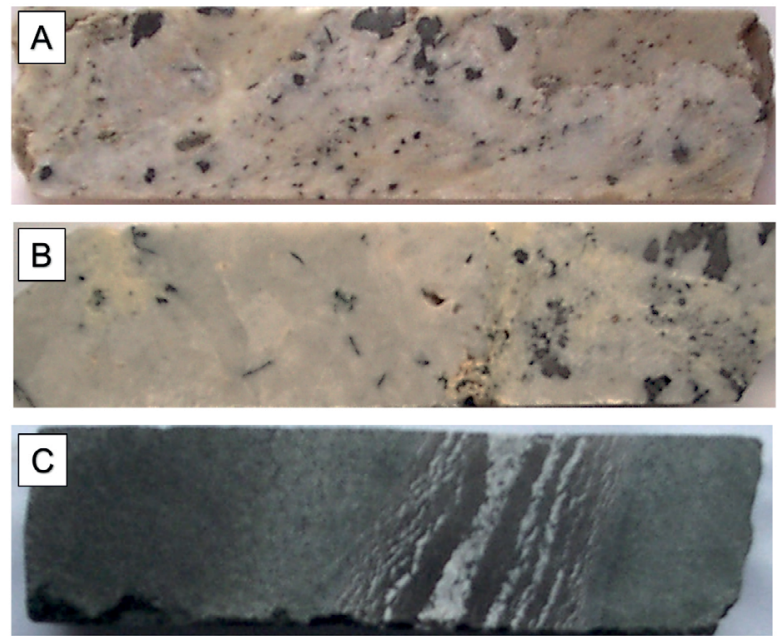

Figure 5. Drill core photos with a diameter of $47.6 \mathrm{~mm}$. (A) Coarse-grained beforsite, (B) Fine-grained beforsite, and (C) Jacupirangite with reaction zone (fenite). 
aiming for their technical and economic exploitation. The study carried out in the Mesquita Sampaio area was based on previous mineral exploration data performed by Bunge Fertilizantes (now Mosaic Fertilizantes) in 2003, where, in the first stage, gravimetric geophysical surveys were executed in sections with 250 meters spacing, and station locations spaced 25 meters along each section (Shukowsky et al. 2003). The results served as indicative of initial targets guiding for the location of the first drillholes and a second gravimetric survey, carried out in a regular spacing of 25 by 25 meters. The geological interpretation of drillhole data was performed through parallel vertical sections that delimited the contacts of the recognized geological units. Then, using the software Gems 5.5, the interpretations were generated in horizontal sections spaced 10 by 10 meters. To obtain the wireframe solid, the extrusion technique (Gems 5.5) was applied, which consists of extrapolating the information generated in the plant and then joining it level-by-level, obtaining a continuous solid that represents the dimensional model (Fig. 6).

Of the four lithotypes defined for Mesquita Sampaio, only the XEN could not be represented in the $3 \mathrm{D}$ geological model due to a scale matter, as these zones are commonly centimetric and the model reproduces geological units at least on the metric scale. The 3D geological model shows the Mesquita Sampaio beforsites as a vertical body with an NNW direction with approximately 350 meters in length and 150 meters in width of known dimensions. CGB is predominant in the northern portion of the pipe, while in the southern, FGB is (Fig. 6). Two jacupirangite xenoliths of approximately 100 meters in length could be individualized within the beforsite bodies (Fig. 6). With current knowledge, the Mesquita Sampaio carbonatite body reaches $400 \mathrm{~m}$ in depth with open continuity. The shape of the Mesquita Sampaio carbonatite suggests a secondary pipe or diatreme structure concerning the main Morro da Mina carbonatite body, although the temporal relations between them are still not clear due to the small number of drillholes.

\section{Mineralogy and petrography}

The identification of the 26 mineral species for Mesquita Sampaio beforsite (Tab. 2) was obtained by comparing the sample diffractograms to the ICDD database. From the total identified mineral phases, only eight mineral species (dolomite, fluorapatite, phlogopite, lizardite, calcite, magnetite, hydroxylapatite, and kinoshitalite) occur in all eighteen samples analyzed by XRD. The three members, fluorapatite, hydroxylapatite, and chlorapatite are not easily distinguishable from XRD data, as well as in petrography. Menezes and Martins (1984) described fluorapatite in the Morro da Mina carbonatite. In this study, the minerals of the apatite group are treated as apatite indistinctly. The same occurs for serpentine group minerals, being treated in this work as serpentine. A representative main mineral assemblage of the Mesquita Sampaio beforsite is dolomite, apatite, phlogopite, serpentine, calcite, and magnetite, being described from greater to smaller abundance. Ilmenite, pyrite, quartz, and titanomagnetite were identified in several

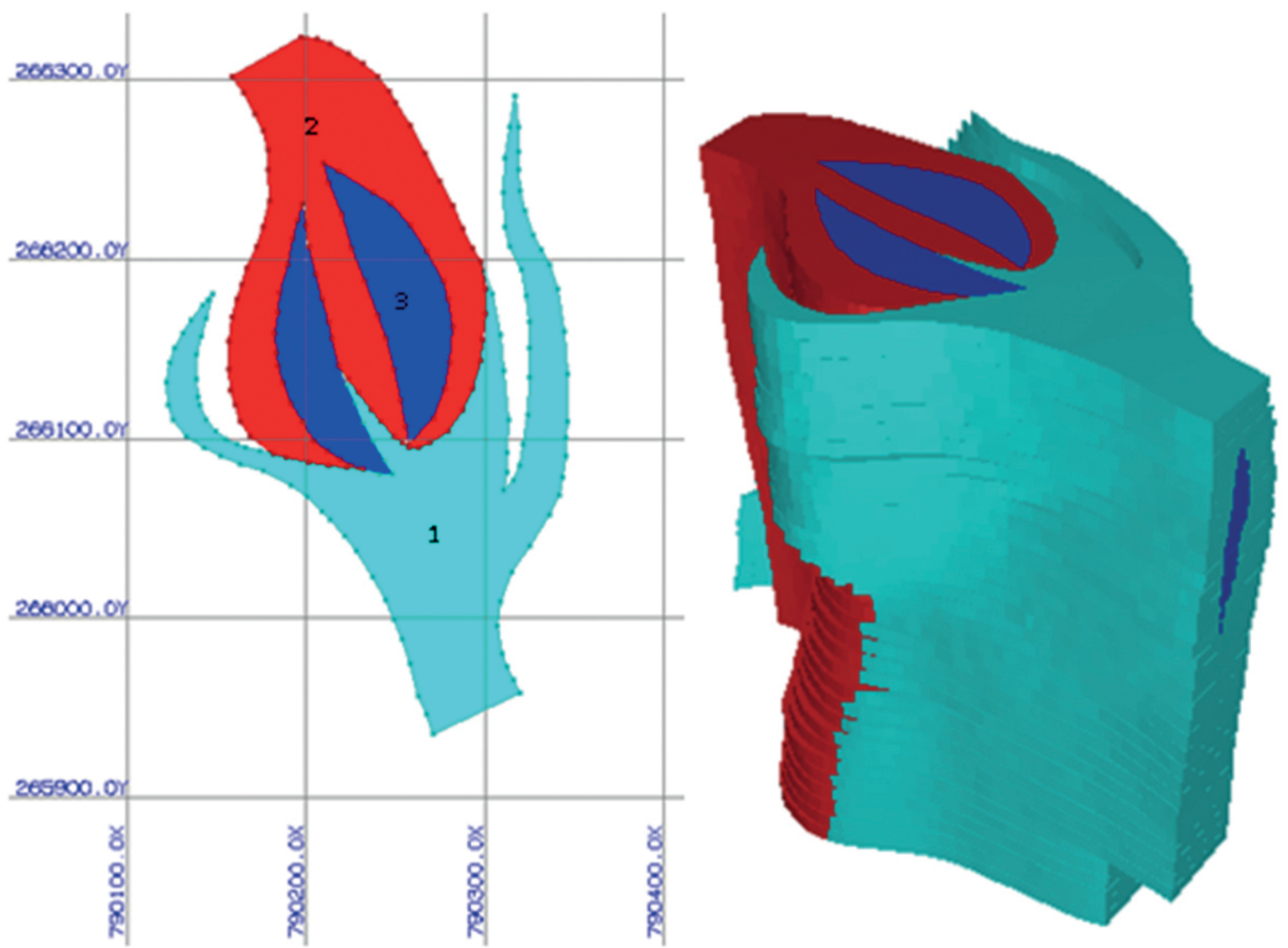

Figure 6. 3D geological model of Mesquita Sampaio. (1) Fine-grained beforsite (FGB), (2) Coarse-grained beforsite (CGB), and (3) Jacupirangite (JAC). 
samples, being frequent accessories, while the other mineral phases were not confirmed by petrography studies and were identified in only one or two samples each, requiring other more specific studies for their confirmation.

Considering the modal estimation of the mineral phases occurring in the dolomite carbonatites of Mesquita Sampaio, between 75 and $85 \%$ of the ore-forming minerals are dolomite (mainly) and calcite. The second mineral that most occurs in these rocks is apatite (on average $10 \%$ ), followed by opaque minerals, mainly magnetite $(6 \%)$, and phlogopite (2\%), which generally presents inverted pleochroism in orange-brown to greenish tones. The apatite occurs in fine-grained size, variably concentrated in small portions or along magmatic flow foliation. Perovskite and minerals of the pyrochlore group occur as trace minerals and were not identified in XRD studies. The carbonates presented in general medium grain size, with crystallization in two phases, from crystals of 0.02 to $5 \mathrm{~mm}$.

In both beforsites (FGB and CGB), the apatite occurs elongated, sometimes in a magmatic flow foliation, concentrated in local portions without preferential orientation. Both apatite as carbonates seem to have been simultaneously crystallized, from initial stages until later. Opaque occurs involving carbonates and filling interstices, suggesting that they are subsequent to them (Figs. 7A and 7B). The phlogopite occurs brownish euhedral with a pseudohexagonal habit, suggesting a stage of primary crystallization, and also occurs from orange-brown to

Table 2. Identified minerals by X-ray diffraction (XRD) in the Mesquita Sampaio beforsite, with International Centre for Diffraction Data (ICDD) card number.

\begin{tabular}{|c|c|c|}
\hline ICDD & Mineral & Chemical formula \\
\hline 00-036-0426 & Dolomite & $\mathrm{CaMg}\left(\mathrm{CO}_{3}\right)_{2}$ \\
\hline 01-086-2348 & Magnesite & $\mathrm{MgCO}_{3}$ \\
\hline 00-012-0088 & Ankerite & $\mathrm{Ca}(\mathrm{Mg}, \mathrm{Fe})\left(\mathrm{CO}_{3}\right)_{2}$ \\
\hline 01-081-2027 & Calcite & $\mathrm{CaCO}_{3}$ \\
\hline 01-070-0796 & Fluorapatite & $\mathrm{Ca}_{4.895}\left(\mathrm{PO}_{4}\right)_{2.995} \mathrm{Cl}_{0.23} \mathrm{~F}_{0.77}(\mathrm{OH})_{0.35}$ \\
\hline 01-082-1429 & Hydroxylapatite & $\mathrm{Ca}_{10.084}\left(\mathrm{PO}_{4}\right)_{5.94}(\mathrm{OH})_{3.39}$ \\
\hline 01-073-1728 & Chloroapatite & $\mathrm{Ca}_{5}\left(\mathrm{PO}_{4}\right)_{3} \mathrm{Cl}$ \\
\hline 00-024-0867 & Phlogopite & $\mathrm{KMg}_{3} \mathrm{AlSi}_{3} \mathrm{O}_{10} \mathrm{~F}_{2}$ \\
\hline 01-083-1366 & Biotite & $\begin{array}{l}\mathrm{K}_{2}\left(\mathrm{Fe}_{2.786} \mathrm{Mg}_{2.321} \mathrm{Ti}_{0.550}\right) \\
\left(\mathrm{Al}_{2.413} \mathrm{Si}_{5.587} \mathrm{O}_{2}\right)(\mathrm{OH})_{4}\end{array}$ \\
\hline 00-034-0166 & Vermiculite & $(\mathrm{Mg}, \mathrm{Al})_{3}(\mathrm{Si}, \mathrm{Al})_{4} \mathrm{O}_{10}(\mathrm{OH})_{2.4} \mathrm{H}_{2} \mathrm{O}$ \\
\hline 00-043-1491 & Cebollite & $\mathrm{Ca}_{2} \mathrm{MgSi}_{2}(\mathrm{O}, \mathrm{OH})_{7}$ \\
\hline 00-050-1606 & Lizardite & $(\mathrm{Mg}, \mathrm{Fe})_{3} \mathrm{Si}_{2} \mathrm{O}_{5}(\mathrm{OH})_{4}$ \\
\hline $00-052-1572$ & Antigorite & $\mathrm{Mg} 3 \mathrm{Si} 2 \mathrm{O} 5(\mathrm{OH}) 4$ \\
\hline 01-071-1140 & Ilmenite & $\mathrm{FeTiO}_{2}$ \\
\hline 01-075-1376 & Titanomagnetite & $\mathrm{Fe}_{2.5} \mathrm{Ti}_{0.5} \mathrm{O}_{4}$ \\
\hline 01-089-0951 & Magnetite & $\mathrm{Fe}_{3} \mathrm{O}_{4}$ \\
\hline 00-001-1292 & Rutile & $\mathrm{TiO}_{2}$ \\
\hline 00-048-1873 & Microlite & $(\mathrm{Ca}, \mathrm{Na})_{2}(\mathrm{Ta}, \mathrm{Nb})_{2} \mathrm{O}_{6}(\mathrm{OH}, \mathrm{F})$ \\
\hline 01-071-0053 & Pyrite & $\mathrm{FeS}_{2}$ \\
\hline 00-046-1045 & Quartz & $\mathrm{SiO}_{2}$ \\
\hline 00-029-0180 & Kinoshitalite & $\mathrm{BaMg}_{3} \mathrm{Si}_{2} \mathrm{Al}_{2} \mathrm{O}_{10}(\mathrm{OH})_{2}$ \\
\hline
\end{tabular}

greenish with carbonates and opaque inclusions, presenting features that suggest a post-alteration, generating an aggregate material as light green spots (Figs. 7C and 7D).

The reaction zones, which are characteristic of borders of $\mathrm{XEN}$, have centimetric bands of dolomite associated with apatite in a similar texture to that found in carbonatites. Pseudomorphs of colorless olivine and amphiboles with a fibrous appearance are also characteristic, highlighting the serpentine generation (Figs. 7E and 7F).

The jacupirangite in the Mesquita Sampaio area is a clinopyroxenite formed by opaque minerals (mainly magnetite) in a grain size smaller than the pyroxenes and included or interstitial to them (Figs. 7G and 7H). Phlogopite occurs in orange color, in small amounts, and fine-grained. Perovskite occurs in brown tones normally subhedral in association with opaque minerals.

\section{Lithogeochemistry}

The whole-rock chemical compositions are tabulated by lithotype in Table 3. Mesquita Sampaio carbonatite data are plotted on the International Union of Geological Sciences (IUGS) classificatory diagram (Le Maitre et al. 2002), shown in Figure 8. Samples of Morro da Mina carbonatite from Huang et al. (1995) and Beccaluva et al. (2017) were considered for comparison. All Mesquita Sampaio beforsite data, whether FGB or CGB, lies on the magnesio carbonatite field. The three Morro da Mina carbonatite samples (HB005, HB010, and HB011) from Huang et al. (1995) plot on the iron carbonatite field, while the two samples from Beccaluva et al. (2017) plot on the calcium carbonatite field (Fig. 8). Major elements scatter plots for the Mesquita Sampaio beforsites are shown in Figure 9. The variations of $\mathrm{SiO}_{2}$ reflect the modal proportions of olivine, micas, and serpentine, in addition to the $\mathrm{Fe}_{2} \mathrm{O}_{3}$ content, which also reflects magnetite proportions and some sulfides. The $\mathrm{CaO}$, as well as the carbonates, are in the chemical structure of apatite. The $\mathrm{MgO}$ content is closely linked with the proportions of dolomite but also to the main silicates previously mentioned. The $\mathrm{Al}_{2} \mathrm{O}_{3}$ is related to the micas proportions and the $\mathrm{TiO}_{2}$ to titanomagnetite and ilmenite mainly. In general, in all geochemical scatter plots of Figure 9, a small variability of mineral amounts could be noted for the two lithotypes of the Mesquita Sampaio area.

In addition to having higher $\mathrm{MgO}$ values than Morro da Mina carbonatites, the Mesquita Sampaio beforsites have chemical compositions between mine carbonatite ranges intervals reported in the literature (Huang et al. 1995, Beccaluva et al. 2017). The Mesquita Sampaio beforsite has $\mathrm{CaO}$ values from 31.3 to $32.7 \%$ and $\mathrm{Fe}_{2} \mathrm{O}_{3}$ values from 0.83 to $4.23 \%$, while in the Morro da Mina carbonatite the values range from 28.6 to $50.7 \%$ and from 0.10 to $43.1 \%$, respectively. These values reflect variations on dolomite, calcite and ankerite amounts or even the absence of one of these carbonates within the two contiguous carbonatites. The $\mathrm{Al}_{2} \mathrm{O}_{3}$ values vary from 0.18 to $0.34 \%$ in the Mesquita Sampaio beforsites and the Morro da Mina carbonatites the values vary from 0.10 to $1.20 \%$ reflecting different proportions in micas, mainly phlogopite. The $\mathrm{P}_{2} \mathrm{O}_{5}$ and $\mathrm{TiO}_{2}$ values in the beforsites ( 3.07 to $6.00 \% ; 0.17$ to $0.62 \%$, respectively) are also contained within the value ranges of the 

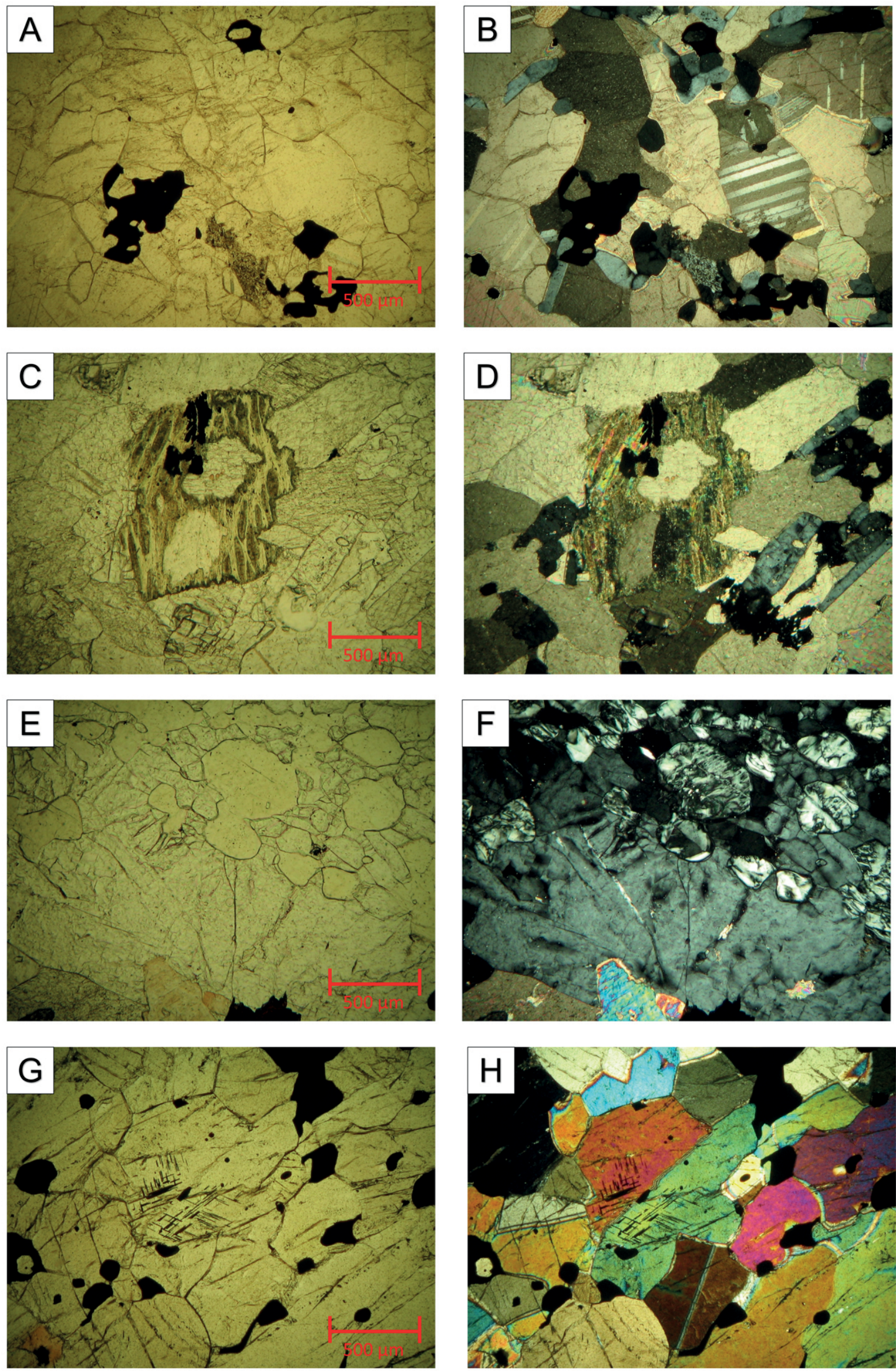

Figure 7. Photomicrographs of the Mesquita Sampaio lithotypes. Beforsite with geminate carbonates (dolomite mostly) and opaque (magnetite mostly) both involving carbonates and interstitial to them with (A) open nicol and with (B) cross nicol. Beforsite with corroded phlogopite in reaction with carbonates and with associated opaque, apatite (gray color) in magmatic flow foliation with (C) open nicol and with (D) cross nicol. Reaction zone between carbonates and phlogopite with greenish reaction stains (lower portion) and pseudomorphs of colorless olivine (upper portion) (E) open nicol and with (F) cross nicol. Jacupirangite with clinopyroxenes (yellow to green interference color) in granular texture with associated opaque minerals (magnetite mostly) with (G) open nicol and with (H) cross nicol. 
Braz. J. Geol. (2020), 50(3): e20190071

Table 3. Bulk rock major element compositions of the Mesquita Sampaio beforsite. In blank, not determined elements.

\begin{tabular}{|c|c|c|c|c|}
\hline & $\begin{array}{c}\text { SP45- } 440.00 \mathrm{~m} \\
\text { Fine-grained beforsite }\end{array}$ & $\begin{array}{c}\text { SP46-212.65 m } \\
\text { Fine-grained beforsite }\end{array}$ & $\begin{array}{c}\text { SP43-177.30 m } \\
\text { Coarse-grained beforsite }\end{array}$ & $\begin{array}{c}\text { SP50-400.00 m } \\
\text { Coarse-grained beforsite }\end{array}$ \\
\hline $\mathrm{SiO}_{2}$ & 0.59 & 1.57 & 1.70 & 0.23 \\
\hline $\mathrm{CaO}$ & 32.70 & 31.26 & 32.50 & 32.70 \\
\hline $\mathrm{MgO}$ & 19.37 & 17.56 & 18.20 & 19.70 \\
\hline $\mathrm{Al}_{2} \mathrm{O}_{3}$ & 0.21 & 0.34 & 0.18 & \\
\hline $\mathrm{Fe}_{2} \mathrm{O}_{3}$ & 1.56 & 4.23 & 3.52 & 0.83 \\
\hline $\mathrm{P}_{2} \mathrm{O}_{5}$ & 3.07 & 4.01 & 6.00 & 3.14 \\
\hline $\mathrm{TiO}_{2}$ & & 0.62 & 0.17 & \\
\hline $\mathrm{SrO}$ & 0.60 & 0.57 & 0.66 & 0.65 \\
\hline $\mathrm{MnO}$ & 0.24 & 0.26 & 0.25 & 0.27 \\
\hline LOI & 41.11 & 39.74 & 37.10 & 42.30 \\
\hline
\end{tabular}

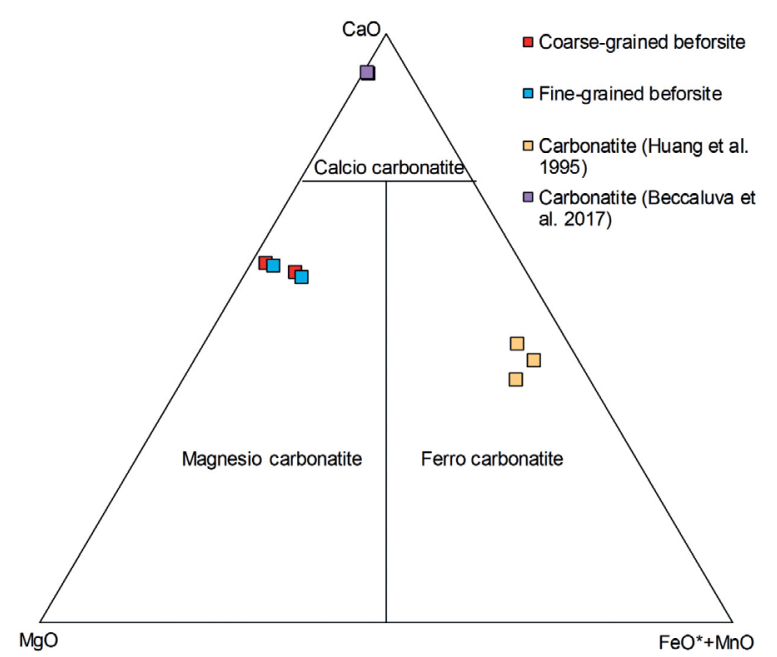

Figure 8. Ternary IUGS classification diagram for carbonatites (Le Maitre et al. 2002) with samples from the Mesquita Sampaio beforsite.

Morro da Mina carbonatites ( 0.10 to $9.80 \%$; 0.01 to $1.30 \%$, respectively), reflecting different proportions in the accessory minerals identified in petrography and XRD analysis, such as apatite, titanomagnetite, and ilmenite.

\section{DISCUSSION}

The 3D geological modeling delineates a beforsite pipe with significant dimensions ( 350 x 150 meters), though smaller than the Morro da Mina carbonatite, which has at least $1 \mathrm{~km}$ of extension along its main strike. The main feature of the Mesquita Sampaio carbonatite is its magnesian composition. Dolomite carbonatites are described in the Morro da Mina as a product of late processes (Gaspar and Wyllie 1983b, Gaspar 1989, Saito et al. 2004). In some mine regions, it appears to be a swarm of beforsite dikes intruding the sovites, but in other regions, the increase in dolomite could be attributed to a metasomatic process of dolomitization of the sovite (Gaspar and Wyllie 1983b). The textures observed in the Mesquita Sampaio beforsite are not from veins or replacement, but rather primary and not similar to the dolomite carbonatites described in the mine. The normal sequence of cationic abundances in the carbonatite rock is: $\mathrm{Ca}>\mathrm{Mg}>\mathrm{Fe}>(\mathrm{Na}+\mathrm{K})$ (Le Bas 1981). One hypothesis would be that considering the Mesquita Sampaio as a late intrusion, it could be the generator of the Morro da Mina dolomite carbonatite dikes and dolomitization, due also to the proximity of these dolomitic occurrences, present in the northern portion of the mine, to the Mesquita Sampaio area. For while no direct contact relation between Mesquita Sampaio and Morro da Mina is known, both may be the same carbonatitic body with a gradual variation of the composition, or the Mesquita Sampaio is a distinct late or even earlier carbonatite pipe.

The Mesquita Sampaio beforsite subdivision in two lithotypes based on rock grain size do not reflect great chemical differences (Tab. 3), which means that both lithotypes have the same mineralogy, but in different modal proportions. The same occurs when comparing the chemical composition and mineralogy of the Mesquita Sampaio beforsite with the data in the literature for the Morro da Mina carbonatite (Menezes and Martins 1984, Gaspar 1989, Huang et al. 1995, Beccaluva et al. 2017). The similarities of geochemical and mineralogical data for the carbonatites in the Mesquita Sampaio with the Morro da Mina data suggest a parental relationship between both. However, geochemical studies with trace elements and isotopes are necessary to confirm this hypothesis. At the present stage of knowledge, the overlapped major elements compositions only indicate similar mineralogical compositions for the two carbonatites.

The apatite-bearing Mesquita Sampaio beforsite, although with small dimensions, is a potentially additional ore source to the phosphate mine, however detailed economic studies are still necessary to confirm its economic viability.

\section{CONCLUSIONS}

- The 3D geological modeling based on the first eleven drillholes defined a subvertical carbonatite body of hundreds of meters scale in an NNW direction with depth extension confirmed until 400 meters. The 3D model of the Mesquita Sampaio also differentiated a coarse-grained beforsite 

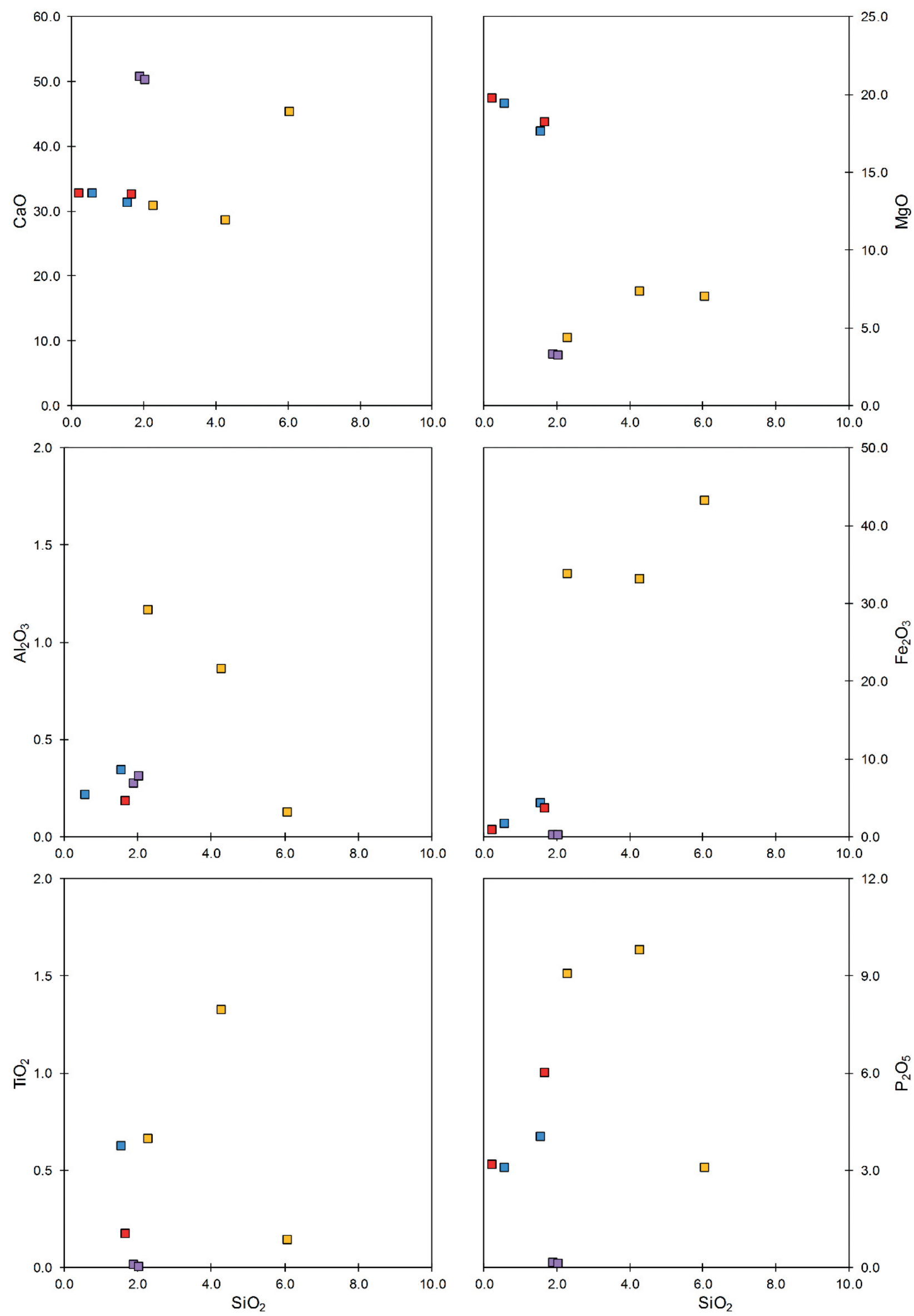

$\square$ Carbonitite (Beccaluva et al. 2017) $\quad \square$ Carbonatite (Huang et al. 1995)

$\square$ Coarse-grained beforsite

$\square$ Fine-grained beforsite

Figure 9. Selected Harker diagrams for the Mesquita Sampaio beforsite. 
(CGB) in the northern portion of the pipe structure, and a fine-grained beforsite (FGB) in the southern portion;

- A representative main mineral assemblage of the Mesquita Sampaio beforsite is dolomite, apatite, phlogopite, serpentine, calcite, and magnetite, in abundance order. All these minerals have also been described in the contiguous Morro da Mina carbonatite;

- The temporal relation between the Mesquita Sampaio and the Morro da Mina carbonatites are still not clear, but the close results of mineralogy, geochemistry, the direction of intrusion, and spatial location suggest a parental relationship between both.

\section{ACKNOWLEDGMENTS}

The authors would like to thank the Mosaic Fertilizantes Company, in the name of Agenor Faria and Marcia Saito, for allowing the use of the database. We also would like to thank the two anonymous reviewers for their suggestions and comments, which surely improved the quality of the paper.

\section{ARTICLE INFORMATION}

Manuscript ID: 20190071. Received on: 08/01/2019. Approved on: 05/11/2020.

S.B.O. wrote the draft of the manuscript, reviewed and edited, and prepared the images and tables, L.M.S. supervised and revised the original version of the text.

Competing interests: The authors declare no competing interests.

\section{REFERENCES}

Almeida F.F. 1983. Relações Tectônicas Das Rochas Alcalinas Mesozóicas Da Região Meridional Da Plataforma Sul-Americana. Revista Brasileira de Geociências, 13(3):139-158.

Amaral G. 1978. Potassium-Argon Age Studies On The Jacupiranga Alkaline District, State Of São Paulo, Brazil. In: International Symposium On Carbonatites, 1., 1978. Proceedings... Poços de Caldas, p. 295-302.

Bauer H.E. 1877. As Minas De Ferro De Jacupiranga. Revista de Engenharia, 170:213.

Beccaluva L., Bianchini G., Natali C., Siena F. 2017. The AlkalineCarbonatite Complex Of Jacupiranga (Brazil): Magma Genesis And Mode Of Emplacement. Gondwana Research, 44:157-177. https://doi. org/10.1016/j.gr.2016.11.010

Bonas T.B. 2007. Aplicação de índice mineralógico como apoio na avaliação de reservas da mina de fosfato de Cajati-SP. Thesis, Universidade de São Paulo, São Paulo, 80 p.

Chmyz L., Arnaud N., Biondi J.C., Azzone R.G., Bosch D., Ruberti E. 2017. Ar-Ar Ages, Sr-Nd Isotope Geochemistry, And Implications For The Origin Of The Silicate Rocks Of The Jacupiranga Ultramafic-Alkaline Complex (Brazil). Journal Of South American Earth Sciences, 77:286-309. https://doi. org/10.1016/j.jsames.2017.05.009

Derby O.A. 1891. On The Magnetite Ore Districts Of Jacupiranga And Ipanema. Sao Paulo. Brazil. American Journal Of Science (1880-1910), 41:311-321. https://doi.org/10.2475/ajs.s3-41.244.311

Faleiros F.M., Pavan M. 2013. Geologia E Recursos Minerais Da Folha Eldorado Paulista-SG-22-XB-XI, Estado De São Paulo. Escala: 1:100.000. São Paulo: Companhia De Pesquisa De Recursos Minerais, CPRM.

Gaspar J.C. 1989. Geologie Et Mineralogy Du Complexe Carbonatique De Jacupiranga, Brésil. PhD Thesis, University of Orleans, Orleans.

Gaspar J.C., Wyllie P.J. 1983a. Ilmenite (High Mg, Mn, Nb) In The Carbonatites From The Jacupiranga Complex, Brazil. American Mineralogist, 68(9-10):960-971.

Gaspar J.C., Wyllie P.J. 1983b. Magnetite In The Carbonatites From The Jacupiranga Complex, Brazil. American Mineralogist, 68:195-213.

Germann A., Marker A., Friedrich G. 1987. The Alkaline Complex Of Jacupiranga, São Paulo/Brazil-Petrology And Genetic Considerations. Zentralblatt Für Geologie Und Paläontologie, 1:807-818.

Gomes C.B., Ruberti E., Comin-Chiaramonti P., Azzone R.G. 2011. Alkaline Magmatism In The Ponta Grossa Arch, SE Brazil: A Review. Journal Of South American Earth Sciences, 32(2):152-168. https://doi.org/10.1016/j. jsames.2011.05.003

Huang Y.M., Hawkesworth C.J., Van Calsteren P., McDermott F. 1995. Geochemical Characteristics And Origin Of The Jacupiranga
Carbonatites, Brazil. Chemical Geology, 119(1-4):79-99. https://doi. org/10.1016/0009-2541(94)00093-n

Hussak E. 1892. Ueber Brazilit, Ein Neues Tantal (Niob) Mineral Von Der Eisenmine Jacupiranga. Neues Jahrbuch Für Mineralogie, 2:141-159.

Le Bas M.J. 1981. Carbonatite Magmas. Mineralogical Magazine, 44(334):133-140. http://doi.org/10.1180/Minmag.1981.044.334.02

Le Maitre R.W., Streckeisen A., Zanettin B., Le Bas M.J., Bonin B., Bateman P. (2002) Igneous Rocks: A Classification And Glossary Of Terms: Recommendations Of The International Union Of Geological Sciences Subcommission On The Systematics Of Igneous Rocks. Cambridge: Cambridge University Press.

Melcher G.C. 1965. O carbonatito de Jacupiranga. Boletim de Geologia, (21):5-70. http://dx.doi.org/10.11606/issn.2526-3862. bffcluspgeologia.1965.121895

Melcher G.C. 1966. The Carbonatites Of Jacupiranga, São Paulo, Brazil. Carbonatites 169:1361-1382.

Menezes L.A.D., Martins J.M. 1984. The Jacupiranga Mine, São Paulo, Brazil. Mineralogical Record, 15:261-270.

Morbidelli L., Beccaluva L., Brotzu P., Conte A., Garbarino C., Gomes C.B., Macciotta G., Ruberti E., Scheibe L.F., Traversa G. 1986. Petrological And Geochemical Studies Of Alkaline Rocks From Continental Brazil. Fenitization Of Jacupiranguite By Carbonatite Magmas In The Jacupiranga Complex, SP. In: Congresso Brasileiro de Geoquímica. Annals... Porto Alegre, p. 261-295.

Roden M.F., Murthy V.R., Gaspar J.C. 1985. Sr And Nd Isotopic Composition Of The Jacupiranga Carbonatite. The Journal Of Geology, 93(2):212-220. http://doi.org/10.1086/628943

Ruberti E., Gomes C.B., Comin-Chiaramonti P. 2005. The Alkaline Magmatism From The Ponta Grossa Arch. In: Comin-Chiaramonti P. Gomes C.B. (Eds.). Mesozoic To Cenozoic Alkaline Magmatism In The Brazilian Platform. São Paulo: Edusp/Fapesp, p. 473-521.

Saito M.M., Barros G., Bonás T.B., Bettencourt J.S. 2004. Mapeamento Geológico De Detalhe Da Mina De Cajati (SP): Modelo Conceitual E Aplicação À Lavra, Produção E Beneficiamento. In: Congresso Brasileiro De Geologia. Annals... Araxá, p. 785-786.

Sant'Agostino L.M., Alves P.R., Shimabukuro N., Bonás T.B. 2001. Applied Mineralogy As A Tool For Mine Planning Of Phosphate Rock. Minerals Engineering, 14(12):1649-1657. https://doi.org/10.1016/ s0892-6875(01)00183-2

Shukowsky W., Mantovani M.S.M., Bonás T.B. 2003. Gravity Prospecting For Carbonatite At The Jacupiranga Alkaline Complex, Brazil. In: International Congress Of The Brazilian Geophysical Society, 8., 2003. Annals... Rio de Janeiro: Brazilian Geophysical Society, p. 4. 